\title{
Fire history of the Rochelle Hills Thunder Basin National Grasslands
}

\author{
BARRY L. PERRYMAN AND W.A. LAYCOCK
}

Authors are assistant professor, School of Veterinary Medicine, University of Nevada, Reno, Nev. 89557, and professor emeritus, Department of Renewable Resources, University of Wyoming, Laramie, Wyo. 82071. Research was funded by the McIntire-Stennis Ecosystem Management Program and the Department of Rangeland Ecology and Watershed Management, University of Wyoming, Laramie, Wyo.

\begin{abstract}
A fire scar chronology was constructed from ponderosa pine (Pinus ponderosa Dougl. ex Laws.) and Rocky Mountain juniper (Juniperus scopulorum Sarg.) trees within the $70 \mathrm{~km}^{2}$ Rochelle Hills Area of the Thunder Basin National Grasslands, in northeast Wyoming. A total of 65 fire scars occurred in 48 crossdated samples, and a master fire chronology was constructed for the period 1565 to 1988 . No trees recorded more than 3 fires and most (26 of 42) recorded only one. For this reason, fire frequency intervals were considered as fire-free intervals in the Rochelle Hills Area. The Weibull Median Probability Interval (WMPI) for the entire period of record was $7.4 ; 7.9$ for the non suppression period (1565 to 1939); and 6.7 for the suppression period (1940 to 1988). Infrequent occurrence of multiple scars, rough topography, and low potential substrates suggest that understory fuel loads were limited in amount and spatial consistency during most fire years. Position of scars within annual growth rings suggests that most fires $(80 \%)$ occurred during the latter stages of the growing season or during the dormant period.
\end{abstract}

Key Words: fire intervals

Fire has been a significant disturbance process in terrestrial ecosystems since the origin of terrestrial vegetation, and lightning-caused fires have been responsible for shaping the structure and composition of most semiarid North American ecosystems (Wright and Bailey 1982). Native Americans used fire to manipulate ecosystems into seral stages favorable for human survival (Barret 1980, Fisher et al. 1987). With European settlement, however, fire suppression became a widespread practice throughout central and western North America, including the grassland ecosystems of northeast Wyoming.

Wendtland and Dodd (1990) concluded that pre-European settlement fire-return intervals ranged from 15-30 years within the area west of the confluence of the North and South Platte rivers to Fort Laramie Wyo., north to the Black Hills and south to the Kansas border, a northern mixed-grass prairie area similar to northeast Wyoming. Their research, based on a review of pioneer journals, diaries, letters, military records, eye witness accounts, and National Park Service fire records further indicated the firereturn interval has exceeded 50 years since 1935 within the

Authors wish to thank the U.S.D.A. Forest Service, Douglas Ranger District for their cooperation.

Manuscript accepted 5 Feb. 2000

\section{Resumen}

Se construyó una cronologáa de las cicatrices producidas por fuego en arboles de "Ponderosa pine" (Pinus ponderosa Dougl. \& Laws) y "Rocky Mountain Juniper" (Juniperus scopulorum Sarg) localizados dentro del áea de $70 \mathrm{~km}^{2}$ de Rochelle Hills en el "Thunder Basin National Grassland" localizado al nordeste de Wyoming. Un total de 65 cicatrices se registraron en 40 muestras de diferentes fechas, y con ellas se construyo un cronologáa maestra del fuego ocurrido en el periodo de 1585 a 1988. Ning $n$ ábol registró mas de 3 fuegos y la mayoráa (26 de 42) registraron solo uno. Por esta razón, en el áea de Rochelle Hills, los intervalos de frecuencia fuego se consideraron como intervalos libres de fuego. El intervalo de probabilidad de la mediana de Weibull (WMPI) para el periodo completo fue de 7.4; 7.9 para el periodo de no supresión (1565 a 1939) y 6.7 para el periodo de supresión (1940 a 1988). La ocurrencia infrecuente de cicatrices múltiples, la topografáa quebrada y los substratos potenciales bajos sugieren que las cargas de combustible de los estratos bajos fueron limitadas en cantidad y consistencia espacial durante la mayoráa de los años de fuego La posición de las cicatrices dentro de los anillos de crecimiento anual sugieren que la mayoráa de los fuegos $(80 \%)$ ocurrieron durante los ultimas etapas de la estación de crecimiento o durante el periodo de dormancia.

boundaries of Scotts Bluff National Monument. They also determined that fire patch area has decreased, and that the timing of prescribed burns has shifted seasonality from characteristic late summer-early fall burns to late winter-early spring burns. Although much information has been garnered from historic journals, it is not as substantive as empirical evidence. However, very few sites exist within a grassland setting where physical evidence of fire can be obtained.

The Rochelle Hills Area of the Thunder Basin National Grasslands in northeast Wyoming contains relatively small pockets, within the grassland matrix, dominated by ponderosa pine (Pinus ponderosa Dougl. ex Laws.) and Rocky Mountain juniper (Juniperus scopulorum Sarg.), both long-lived species that are known to form fire scars (Thilenius et al. 1995, Ahlefeldt et al. 1992). Fire histories have been developed for ponderosa pine communities in several regions throughout the western United States (Dieterich and Swetnam 1984, Fisher et al. 1987, Baisan and Swetnam 1990, Covington and Moore 1994, Brown and Hull-Sieg 1996). Although fire history research has been con- 
ducted in neighboring ponderosa pine forests (the Black Hills area of Wyoming and South Dakota) (Fisher et al. 1987, Brown and Hull-Sieg 1996), the ponderosa pine areas of northeast Wyoming have not been investigated.

Our objectives were to: 1 ) determine fire frequency of the past few centuries; 2) determine if fire frequency has changed since the initiation of fire suppression; 3 ) determine seasonality of fire occurrence; and 4) assess fire location and size.

\section{Study Area}

The Rochelle Hills Area of the Thunder Basin National Grasslands covers approxi mately $70 \mathrm{~km}^{2}$ in the Powder River Basin of northeastern Wyoming (Latitude $43^{\circ} 32^{\prime}$ $30^{\prime \prime} \mathrm{N}$, Longitude $105^{\circ} 05^{\prime} 00^{\prime \prime} \mathrm{W}$ ) (Fig. 1). Surface bedrock is sedimentary in origin and exposed rocks are Wasatch sandstone, Fort Union shale, and "scoria" or "clinker" formed from the baking of sandstones and shales by burning coal beneath the bedrock. Residual soils predominate on top of the escarpment and on steep slopes only a few centimeters of soil overlies bedrock. Rock outcrops are common on the steepest slopes (Breckenridge et al. 1974).

Mean annual precipitation is $31 \mathrm{~cm}$ (including snowfall precipitation equivalents), and mean annual snowfall is 114 $\mathrm{cm}$. Precipitation occurs predominantly in

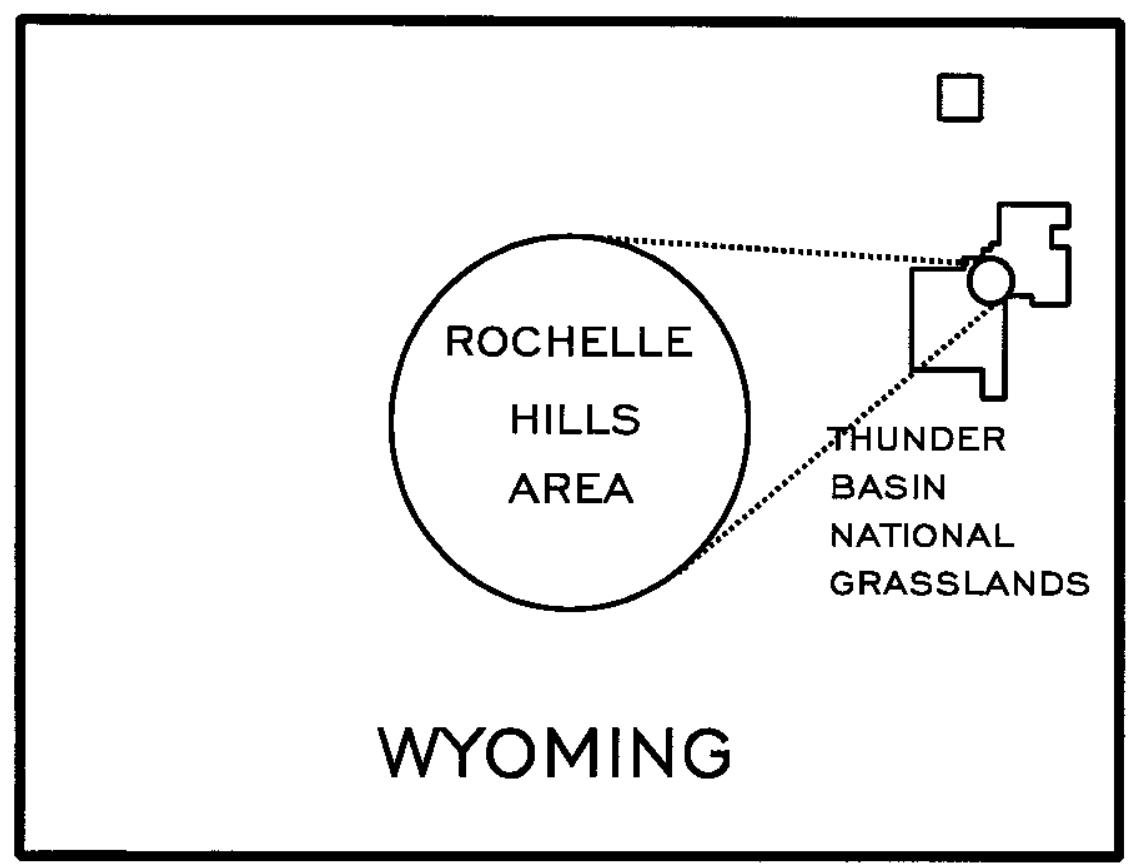

Fig. 1. Location of the Rochelle Hills Area. spring and early summer. The mean annual temperature is $8.1^{\circ} \mathrm{C}$ with 173 days of minimum temperatures below $32^{\circ} \mathrm{C}$. Annual temperature extremes range from $43^{\circ} \mathrm{C}$ to $-44^{\circ} \mathrm{C}$ (Martner 1986).

Trees are present in relatively narrow bands on the top and perimeter slopes of the Rochelle Hills escarpment. Three forest cover types occur in the Rochelle Hills (Thilenius et al. 1995). The Rocky Mountain juniper type occurs on steep, lower slopes at the base of the Rochelle Hills escarpment, and is most abundant on south and western aspects. Junipers grow in shrub form, and the understory vegetation is sparse, has little diversity, and provides little fine fuel production. The ponderosa pine/bluebunch wheatgrass (Agropyron spicatum [Pursh] Schribn. \& Smith) type occupies steep upper slopes and flat areas on top of the escarpment, and it is more prevalent in the eastern portion of the Rochelle Hills. Understory vegetation is more diverse and productive than in the Rocky Mountain juniper type, and Wyoming big sagebrush is present where the canopy is open. The ponderosa pine/Rocky Mountain juniper type is present on western and eastern slopes, but more common in the western portion of the Rochelle Hills and on northern aspects of small canyons. Herbaceous understory vegetation is almost absent and the ground surface is covered with conifer litter to a depth of $10 \mathrm{~cm}$ or more.

Large-scale fire suppression activities were initiated with the availability of sur- plus World War II earth moving equipment and motorized vehicles with capacities to transport large amounts of water. Since approximately 1940 , fires have been vigorously suppressed by government agencies and private land owners ( $\mathrm{J}$. Harshbarger, pers. comm.). We have taken 1940 as the dividing line between suppression and non-suppression periods in the Rochelle Hills.

\section{Materials and Methods}

All forested areas in the Rochelle Hills were surveyed for the presence of fire scarred trees. Scars containing charcoal were assumed to be of fire origin, scars without charcoal were treated as non-fire injuries. Live trees were sampled by employing a combination of methods outlined by McBride and Laven (1976) and Arno and Sneck (1977).

In the laboratory, samples were sanded sequentially with $60,180,320$, and 400 grit sanding belts. Rings were examined with a 10 power stereo microscope to determine seasonality of fire occurrence by identifying scar location within the annual ring. Samples were crossdated to firmly establish fire occurrence years using standard dendrochronologic procedures (Stokes and Smiley 1968). A master fire chronology was then constructed for the entire area. Data analyses were performed using FHX2 Software (GrissinoMayer 1995), and significance was determined at $\mathrm{P}<0.05$.

Kolmogorov-Smirnov Goodness-of-Fit Tests were performed on fire interval distributions to determine if a Weibull distribution (Hallinan 1993) modeled the interval data better than a normal distribution. Fire ecologists have suggested that fire interval data be modeled with a more flexible distribution than the standard normal distribution since fire interval data is often not normally distributed (Johnson and Van Wagner 1985, Johnson 1992, Baker 1992, and Grissino-Mayer 1995). The Weibull distribution is flexible enough to model both normal and negative exponential distributions (Hallinan 1993). Weibull distribution measures of central tendency are as follows: Weibull Median Probability Interval (WMPI); Weibull Fire Frequency Probability (1/WMPI) or the probability that a fire will occur in any given year; and Weibull Exceedance Probability Range (WEPR) or 95\% confidence interval range. (For purposes of this report, the WMPI is used as a synonym for fire intervals). The difference between suppression 
and non-suppression fire interval means was determined by t-test. The FHX2 software transforms Weibull distributions into a data set that approximates the standard normal distribution, allowing the application of statistical tests such as the t-test which require normal distributions (Grissino-Mayer 1995).

A record of the seasonality of fire occurrence was compiled based on fire scar position within the annual rings. Baisan and Swetnam (1990) outlined the seasonal designations utilized: $\mathrm{U}=$ unknown, $\mathrm{E}=$ earlywood (a generic classification, where more precise identification is not possible), $\mathrm{EE}=$ early-earlywood (first $1 / 3$ of earlywood), $\mathrm{ME}=$ middle-earlywood (second $1 / 3$ of earlywood), LE = late-earlywood (last $1 / 3$ of earlywood), L = latewood, and $\mathrm{D}=$ dormant (occurs between 2 rings, year of occurrence depends upon other scars of other trees to assign actual fire year). Each fire scar was examined to determine if the season could be identified. Seasonality summaries were based on fire years (year when a fire was recorded in the proxy record) rather than individual fires or scars.

\section{Results}

\section{Fire History}

A total of 65 fire scars were identified in 48 dateable samples from ponderosa pine (46 trees) and Rocky Mountain juniper trees ( 2 trees). These scars represent 42 different fire years between 1565 and 1988. Multiple scars were recorded on 16 trees. One tree recorded 3 scars and the rest recorded 2. A master fire chronology graph is displayed in Fig. 2.

Statistical analyses (KolmogorovSmirnov Test for Goodness-of-Fit) indicated non-normal distribution of the interval data and that a Weibull distribution modeled fire interval data adequately $(\mathrm{P}=$ 0.41). Central tendency measurements were therefore based on a Weibull distribution. Intervals reported here are fire-free intervals rather than fire-return intervals since trees exhibiting multiple scars were few. Romme (1980) and Wright and Bailey (1982) specify that fire-return interval refers to a point (i.e., a tree) or a very small stand, whereas fire-free interval refers to an area larger than a small stand. Mean fire-free interval is calculated using all fires that occured in a given or specified amount of ground surface area, and the area size must be specified. In other words, the fire-free interval expresses the mean interval between all fires that

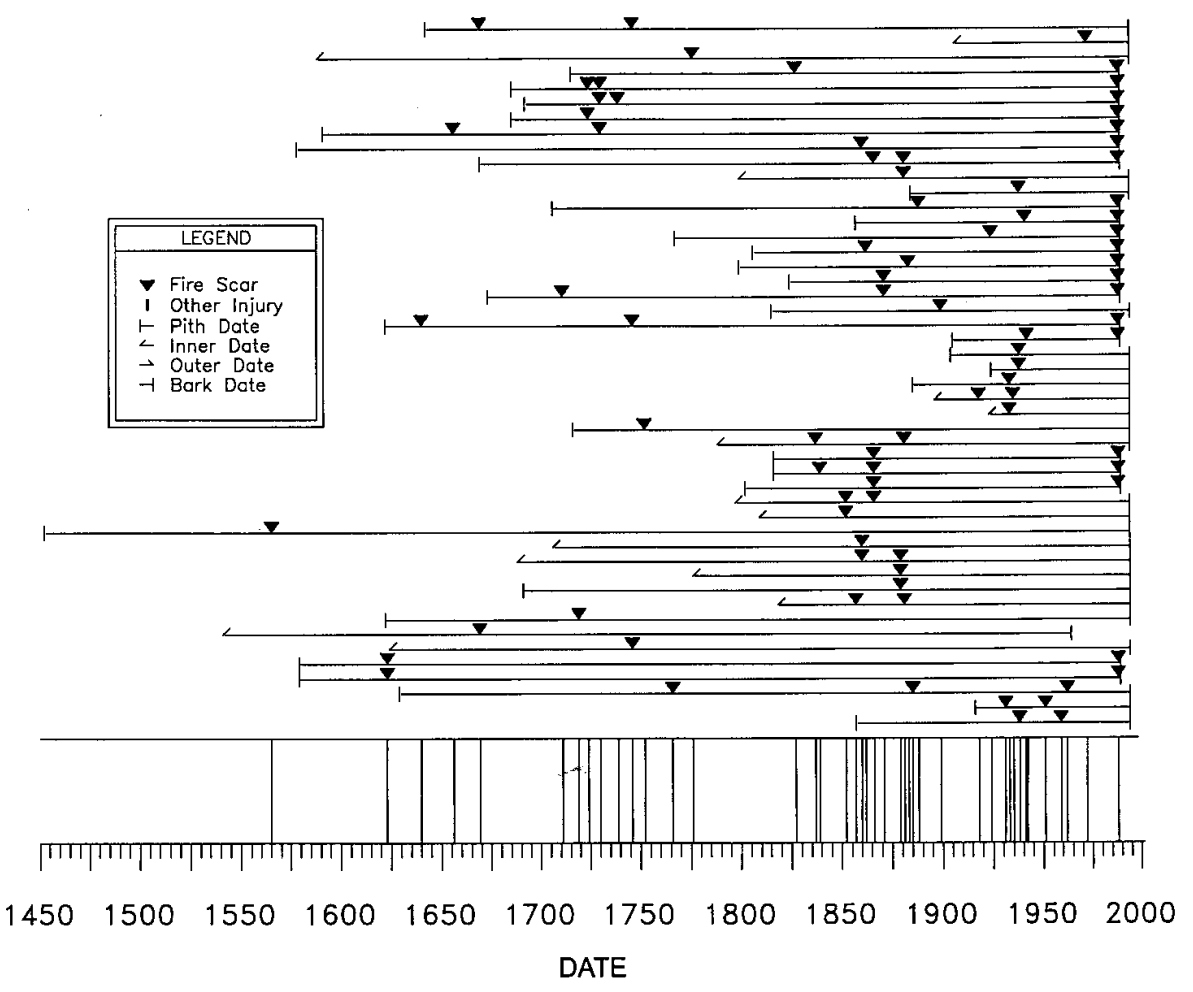

Fig. 2. Master fire chronology.

occurred during a period of record within a given area of land surface. The Rochelle Hills Area is the specified area in this case and covers approximately $70 \mathrm{~km}^{2}$. The lack of multiple scars on single trees (points) mandates the use of fire-free intervals because, in this case where only 15 trees contained as many as 2 scars, a maximum of only 15 intervals would have been available to calculate the mean firereturn interval.

The Weibull Median Probability Interval (WMPI) of the entire period of record (1565 to 1988$)$ is $7.4(n=42)$, with a Weibull Fire Frequency Probability (WFFP) of 0.14 , and a Weibull Exceedance Probability Range (WEPR) of 1.1-22.0. The non suppression period (1565-1940) has a WMPI of $7.9(n=34)$, with WFFP of 0.13 . The WEPR is 1.2 to 23.0. The suppression period (1940-1988) has a WMPI of $6.7(n=8)$, with a WFFP of 0.15 and WEPR of 1.0 to 21.0. There is no difference between the non-suppression and suppression period mean fire-free intervals $(\mathrm{P}=0.69)$.

Within the non-suppression period composite chronology, the proxy evidence recorded several subperiods of alternating high fire frequencies and relatively long periods of no recorded fire years. Three long fire-free intervals occurred between 1566 and 1622, 1670 and 1710, and 1777 and 1826 ; that is 56,40 , and 49 years, respec- tively. Each of these intervals is followed by a period of more frequent fire years.

\section{Seasonality}

Seasonality results (Table 1) are based on fire years (a year when a fire or fires occured) rather than fire scars or individual fires. Basing seasonality on individual scars could introduce bias if a large number of trees were scarred by 1 or more fires during a particular year. The question we are concerned with is in what season(s) of the year have most fires occurred during the period of interest. We believe that using the fire year as a basis of comparison is appropriate in this type of forested system.

Late-season fires dominated the entire period of record. Fire years with late-season fires comprised $80 \%$ (31 of 39) of total fire years. During the non-suppression period, late-season fire years dominated. Combined late-early, late-, and dormant-season fire years comprised 84\% (27 of 32) of the total fire years. Only $16 \%$ were early-season fire years.

The suppression period does not exhibit the same extreme late-season dominance. Only $57 \%$ of the fire years (4 of 7 total fire years) exhibited scars located in the late-early, late, and dormant-season annual ring positions. Sample size was very small for the suppression period, and may be skewing the inference. The scar record 


\begin{tabular}{lccc}
\hline \hline & $\begin{array}{c}\text { Non-suppression } \\
\text { period (1565 to 1940) }\end{array}$ & $\begin{array}{c}\text { Suppression period } \\
\text { (1940 to 1988) }\end{array}$ & $\begin{array}{c}\text { Period of record } \\
(1565 \text { to 1988) }\end{array}$ \\
\hline Total number of scars recorded & 59 & 8 & 67 \\
Samples with identifiable season & 56 & 7 & 63 \\
Samples with undetermined season & 3 & 1 & 4 \\
Early-early season fire years & 1 & 1 & 2 \\
Middle-early season fire years & 4 & 2 & 6 \\
Combined Early Season (early-early and & 5 & 3 & 3 \\
$\quad$ middle-early) fire years & 3 & 0 & 24 \\
Late-early season fire years & 20 & 4 & 4 \\
Late-season fire years & 4 & 4 & 31 \\
Dormant-season fire years & 27 & & $80 \%$ \\
Combined Late-Season (late-early, late, and & & & $20 \%$ \\
$\quad$ dormant season) fire years & $84 \%$ & $57 \%$ & \\
Percent of total late-season fire years & $16 \%$ & $43 \%$ & \\
Percent of total early-season fire years & & & \\
\hline
\end{tabular}

showed no evidence of both early- and lateseason fires occurring in the same year.

\section{Fire location and size}

Of the 42 fire years recorded during the period of record, 14 fire years were recorded by more than 1 tree, and 28 fire years were recorded by only 1 tree. This suggests that most of the recorded fires in this system were either small in area or were without the necessary heat required to scar trees. In either instance, understory fuel loads must have been generally low or discontinuous during most fire years.

The area producing the most scars from different fire years during the period of record was the eastern aspect (Fig.3). There is a question whether this eastern portion of the Rochelle Hills actually burned more often because the topography is more prone to lightning strikes, or rather that the topography and fuel loads were more conducive for scar formation. We believe that the latter is correct. The understory vegetation characteristic of this portion of the study area was dominated by bluebunch wheatgrass and Wyoming big sagebrush (an indicator of high site potential for aboveground herbaceous biomass production). As a result, understory fuel production was probably more consistent, continuous, and volatile than other areas with lower site potential where the understory was dominated by Sandberg bluegrass (Poa secunda Presl., Rel. Haenk) and western yarrow (Achillea lan ulosa Nutt.). Thilenius et al. (1995) indicated that this eastern portion of the study area, characterized by the ponderosa pine/bluebunch wheatgrass vegetation type, had the most well developed understory vegetation stratum in the study area. The grasslands to the east of the Rochelle
Hills also had a more level, unbroken topography, and the potential for more continuous fine fuel loads than the surrounding areas to the north, west, and south. For these reasons, we believe that the eastern portion of the Rochelle Hills has a greater potential for recording fire years in the proxy record.

\section{Discussion and Conclusions}

The mean fire-free intervals (WMPI) of both the non suppression and suppression periods (7.9 and 6.7, respectively) and the entire period of record, 1565 to 1988 (7.4), are consistent with mean fire-return intervals for other northern mixed-grass prairie areas located in the same geographic region. Wright and Bailey (1982) estimated a fire-return interval of approximately 5 years was probable in these grassland systems where topography was level or slightly rolling. Wendtland and Dodd (1990), based on pioneer journals, concluded that fire-return intervals in northern mixed-grass prairie areas (before 1935) were approximately 5 on smooth and gently rolling topography and 15 to 30 on more topographically diverse areas such as Scott's Bluff National Monument. Bragg (1985), using dendrochronology, calculated a mean fire-return interval of 3.5 before 1900 , increasing to 8.5 between 1900 and 1958 in ponderosa pine areas of the Nebraska Sandhills. Brown and Hull-Sieg (1996) calculated the mean fire-return interval between 1668 and 1890 at Jewel Cave in the Black Hills to be 9 to 30 . Shilts et al. (1980) estimated the fire return-interval in the grasslands of Wind Cave National Park to be 13 to 21 between 1820 and 1910. Between 1600 and 1770,
Fisher et al. (1987) estimated a mean firereturn interval of 27 decreasing to 14 between 1770 and 1900 at Devil's Tower National Monument.

There are at least 2 possible explanations for the low numbers of multiple scarred trees and for the majority of fire scars being recorded on only 1 or a few trees for any given fire year. Both are related to fine fuel characteristics. The first implies that fires were frequent, but were relatively small in spatial extent, resulting in only 1 or a few trees being scarred. A second explanation implies that fires were frequent, but possibly larger in spatial extent than in the first explanation. However, spatial discontinuities in the surface fuel load during most fire years, would have carried fires away from previously scarred trees. Both explanations would limit the opportunity for multiple scarring of individual trees and the scarring of trees in general. The second explanation seems more probable as many woodland communities in the north central plains are located where surface fuels are intermittent, discontinuous, and of such low quantity to retard fire spread and lower fire temperature reducing the number of trees scarred over an area and at specific points. This is consistent with the results of a similar study conducted by Brown of the Rocky Mountain Dendrochronology Lab (in prep, Feasibility study for fire history of the North Dakota Badlands: Final Report to Theodore Roosevelt Nature and History Association and Theodore Roosevelt National Park), in the Little Missouri Grasslands of North Dakota, an area very similar to the Rochelle Hills in substrates, topography, and vegetation communities. 


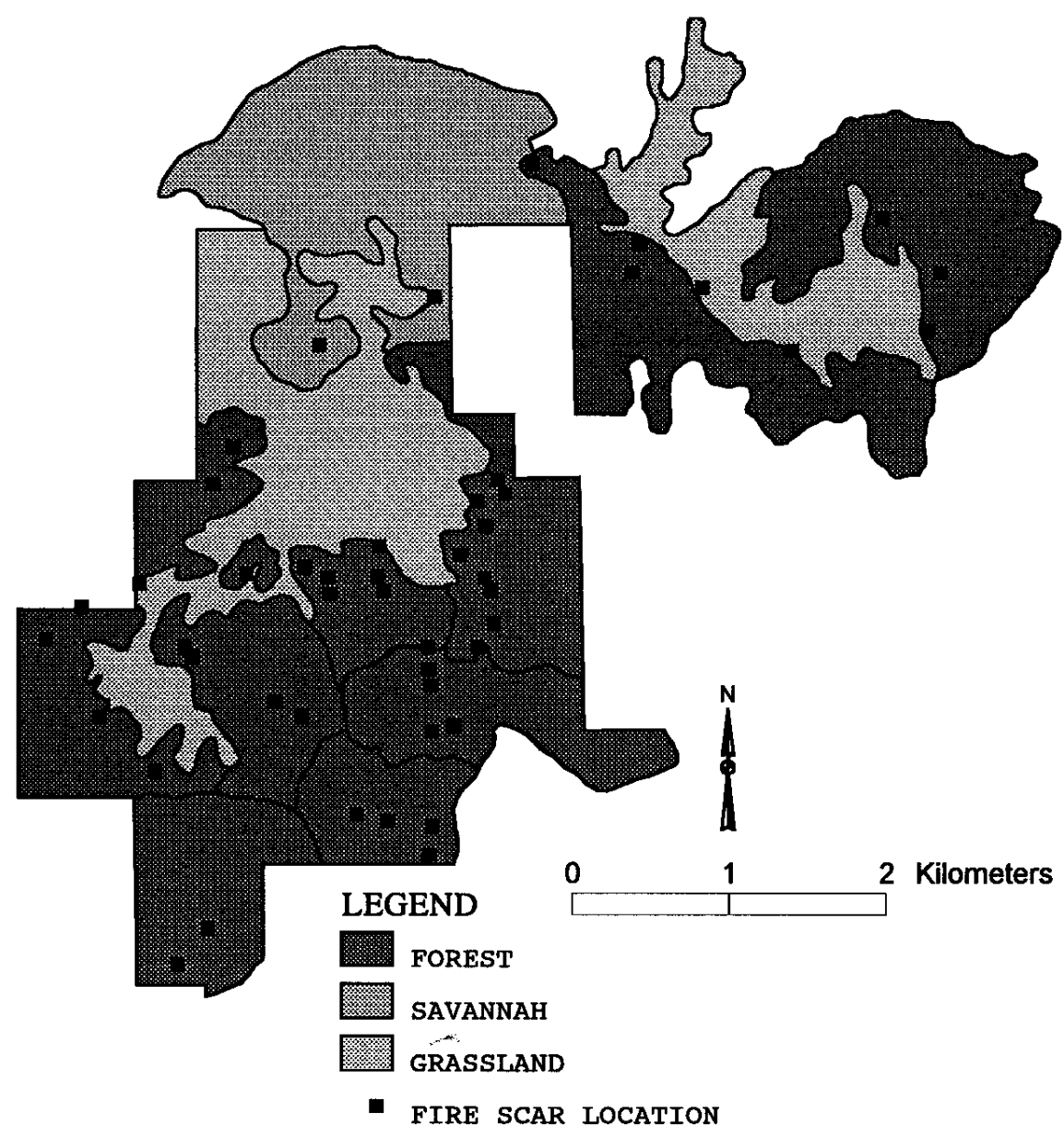

Fig. 3. Fire scar locations.

Thilenius et al. (1995) related that fire scars in the Rochelle Hills were not as common as encountered in ponderosa pine forests in the neighboring Black Hills. Surveying all tree areas for the presence of fire scars ensured confidence that the scar record sampled contained a high percentage of the fires recorded in the Rochelle Hills. Obviously, there is no guarantee that every scarred tree was sampled, or that all fires and fire years were recorded in the surviving proxy record. We therefore suggest that our estimates of fire-free intervals be considered as minimum frequencies. Sample depth is of some concern, particularly during the suppression period $(\mathrm{n}=8)$. The sample depth during the nonsuppression period $(n=34)$ may also be perceived as limited when compared to other fire frequency studies in ponderosa pine forests. As stated earlier, few opportunities exist within grassland settings where physical evidence of fire can be obtained. Tree-covered areas in this region are uncommon and relatively small, limiting the number of samples available for study. (fire breaks), or the potential for fuel discontinuities in the Rochelle Hills that would suggest that fire would be less frequent during suppression times. Considering this, we believe that fire suppression efforts have had little or no effect on the fire-free interval of this system.

The large proportion of fires occurring late in the growing season during the nonsuppression period is similar to results of both Wendtland and Dodd (1990) and Brown and Hull-Sieg (1996). The recent shift in fire occurrence from late season dominance to early season dominance observed by Wendtland and Dodd is similar to our observation. (However, spring season prescription burning has not been practiced in the Rochelle Hills Area, and our observations may be an artifact of low sample size.) Since spring prescription burning has not been employed, there is no reason to suggest that fire seasonality has changed since 1940. More accidental anthropomorphically generated fires may occur in the spring, but this is conjecture. These results also corroborate Higgins' (1984) conclusion that in northern plains grasslands, $73 \%$ of 294 lightning-ignited fires documented between 1940 and 1981 occurred during July and August.

An understory fuel load of sufficient spatial consistency and magnitude to carry a ground fire hot enough to scar trees is probably not present during most years in the Rochelle Hills. Although the fire-free interval has not changed since the initiation of suppression (circa 1940), the longer term effect of suppression is not yet clear. Prior to suppression efforts, fires were probably larger in spatial extent but scarring few trees. Fire size could now be smaller due to suppression. In both instances the potential for multiple scarring of trees would be limited. Suppression and subsequent increases in tree densities and litter accumulations which would normally be consumed by ground fires, could be setting the stage for more frequent stand replacing fires in forested areas. Most of the southern and southwestern forested areas of the Rochelle Hills currently have somewhat closed canopies, substantial amounts of litter accumulations, and relatively high tree densities. This set of circumstances will most likely lead to a future catastrophic fire, but it is unclear if fire suppression activities have given rise to this condition or if this condition is a part of the natural cycle in the ecology of this system. 


\section{Literature Cited}

Ahlefeldt, Judy, von T. Byer, M.R. Edwards, and C. Speas. 1992. Biological Diversity Technical Report for the Thunder Basin National Grassland. Medicine Bow National Forest. Laramie, Wyo. 177 p.

Arno, S.F. and K.M. Sneck. 1977. A method for determining fire history in coniferous forests of the mountain west. U.S. For. Serv. Gen. Tech. Rept. INT-42. 27 p.

Baisan, C.H. and T.W. Swetnam. 1990. Fire history on a desert mountain range, Rincon Mountain Wilderness, Arizona, USA. Can. J. Forest. Res., 20:1559-1569.

Baker, W.L. 1992. The landscape ecology of large disturbances in the design and management of nature reserves. Landscape Ecol., 7:181-194.

Barrett, S.W. 1980. Indian fires in the pre-settlement forests of western Montana. In: Proc. Fire History Workshop, Oct. 20-24, 1980, Univ. Ariz., Tucson. USDA For. Serv. Gen. Tech. Rep. RM-81. 142 p.

Bragg, T.B. 1985. A preliminary fire history of the oak/pine forest of northcentral Nebraska, p.8 In: Proc. 95th Annu. Meeting Nebr. Acad. Sci., Lincoln, Neb. 78 p.

Breckenridge, R.M., G.B. Glass and F.K. Root. 1974. Campbell County, Wyoming [10 maps, Geological maps, atlas and summary]. 1:500,000. CRS-3. Laramie, Wyo: Geological Survey of Wyoming. In cooperation with: Mineral Div. Wyoming Dept. of Econ. Planning and Develop. and U.S. Bur. of Mines. $12 \mathrm{p}$.
Brown, P.M. and C. Hull-Sieg. 1996. Fire history in interior Ponderosa pine communities of the Black Hills, South Dakota, USA. Int. J. Wildland Fire, 6:97-105.

Covington, W.W. and M.M. Moore. 1994. Southwestern ponderosa forest structure changes since euro-American settlement. J. Forest., 92:39-47.

Dieterich. J.H. and T.W. Swetnam. 1984. Dendrochronology of a fire scarred ponderosa pine. Forest. Sci., 30:238-247.

Fisher, R.F., M.J. Jenkins, and W.F. Fisher. 1987. Fire and the prairie-forest mosaic of Devil's Tower National Monument. Amer. Midl. Nat., 117:250-257.

Grissino-Mayer, H.D. 1995. Tree-ring reconstructions of climate and fire history at El Malpais National Monument, New Mexico. Ph.D. Diss. Univ. of Arizona. Tucson, Ariz. $407 \mathrm{p}$.

Hallinan, Jr., A.J. 1993. A review of the Weibull distribution. J. Quality Technol., 25:85-93.

Higgins, K.F. 1984. Lightning fires in North Dakota grasslands and in pine-savanna lands of South Dakota and Montana. J. Range Manage., 37:100-103.

Johnson, E.A. 1992. Fire and Vegetation Dynamics: Studies from the North American Boreal Forest. Cambridge University Press, New York. 129 p.

Johnson, E.A. and C.E. van Wagner. 1985. The theory and use of two fire history models. Can. J. Forest. Res., 15:214-220.

Martner, B.E. 1986. Wyoming Climate Atlas. Wyoming Water Research Center Pub. Univ. of Wyoming. University of Nebraska Press, Lincoln, Neb. 432 p.
McBride, J.R. and R.D. Laven. 1976. Scars as an indicator of fire frequency in the San Bernardino Mountains, California. J. Forest., 74:439-442.

Romme, W.H. 1980. Fire history terminology: Report of the Ad Hoc Committee. In: Proc. Fire History Workshop, Oct. 20-24, 1980, Univ. Ariz., Tucson, Ariz. USDA For. Serv. Gen. Tech. Rep. RM-81. 142 p.

Shilts, D.M., R.W. Klukas, B.L. Freet, and T. Oliverius. 1980. Fire management plan, Wind Cave National Park. Wind Cave National Park, Hot Springs, South Dakota. $178 \mathrm{p}$.

Stokes, M.A. and T.L. Smiley. 1968. An Introduction to Tree-Ring Dating. University of Chicago Press. 73 p.

Thilenius, J.F., G.R. Brown, and A. Medina, 1995. Vegetation on Semi-arid Rangelands, Cheyenne River Basin, WY. U.S.D.A. For. Serv. Gen. Tech. Rept. RM-GTR-263. 60 p.

Wendtland, K.J. and J.L. Dodd. 1990. The fire history of Scott's Bluff National Monument. In: Proc. 12th Annual North American Prairie Conf. p. 141-143.

Wright, H.A., and A.W. Bailey. 1982. Fire Ecology: United States and Canada. John Wiley and Sons, New York. 501 p. 